University of Nebraska - Lincoln

DigitalCommons@University of Nebraska - Lincoln

Daugherty Water for Food Global Institute:

Faculty Publications

Daugherty Water for Food Global Institute

2020

\title{
Water productivity benchmarks: The case of maize and soybean in Nebraska
}

\author{
Mesfin Mekonnen \\ Daugherty Water for Food Global Institute, mmekonnen2@unl.edu \\ Arjen Y. Hoekstra \\ University of Twente, a.y.hoekstra@utwente.nl \\ Christopher Michael Usher Neale \\ University of Nebraska-Lincoln, cneale@nebraska.edu \\ Chittaranjan Ray \\ University of Nebraska-Lincoln, cray@nebraska.edu \\ Haishun Yang \\ University of Nebraska - Lincoln, hyang2@unl.edu
}

Follow this and additional works at: https://digitalcommons.unl.edu/wffdocs

Part of the Environmental Health and Protection Commons, Environmental Monitoring Commons, Hydraulic Engineering Commons, Hydrology Commons, Natural Resource Economics Commons, Natural Resources and Conservation Commons, Natural Resources Management and Policy Commons, Sustainability Commons, and the Water Resource Management Commons

Mekonnen, Mesfin; Hoekstra, Arjen Y.; Neale, Christopher Michael Usher; Ray, Chittaranjan; and Yang, Haishun, "Water productivity benchmarks: The case of maize and soybean in Nebraska" (2020). Daugherty Water for Food Global Institute: Faculty Publications. 98.

https://digitalcommons.unl.edu/wffdocs/98

This Article is brought to you for free and open access by the Daugherty Water for Food Global Institute at DigitalCommons@University of Nebraska - Lincoln. It has been accepted for inclusion in Daugherty Water for Food Global Institute: Faculty Publications by an authorized administrator of DigitalCommons@University of Nebraska Lincoln. 


\title{
Water productivity benchmarks: The case of maize and soybean in Nebraska
}

\author{
Mesfin M. Mekonnen, ${ }^{1}$ Arjen Y. Hoekstra, ${ }^{2,3}$ \\ Christopher M.U. Neale, ${ }^{1}$ Chittaranjan Ray, ${ }^{4}$ \\ \& Haishun S. Yang ${ }^{5}$
}

\begin{abstract}
1 Robert B. Daugherty Water for Food Global Institute, University of Nebraska, Lincoln, NE 68583, USA

2 Twente Water Centre, University of Twente, P.O. Box 217, 7500 AE, Enschede, the Netherlands

3 Institute of Water Policy, Lee Kuan Yew School of Public Policy, National University of Singapore, 469A Bukit Timah Road, 259770, Singapore

4 Nebraska Water Center, Robert B. Daugherty Water for Food Global Institute, University of Nebraska, Lincoln, NE 68583, USA

5 Department of Agronomy and Horticulture, Institute of Agriculture and Natural Resources, University of Nebraska-Lincoln, Lincoln, NE 68583, USA

Corresponding author-M. M. Mekonnen, email mmekonnen2@unl.edu
\end{abstract}

\begin{abstract}
Water productivity benchmarks for irrigated and rainfed agriculture will provide relevant information to manage scarce water resources and control groundwater level decline. We analyze the temporal and spatial variation of the water productivity (WP) of maize and soybean in Nebraska, with WP defined as harvested crop weight per total evapotranspiration. The results show that WP of both maize and soybean increase from west to east within Nebraska and have increased over the last 25 years, mainly due to the increase in crop yields (land productivity). We derive
\end{abstract}

Published in Agricultural Water Management 234 (2020), 106122

doi:10.1016/j.agwat.2020.106122

Copyright (C) 2020 Elsevier B.V. Used by permission.

Submitted 27 August 2019; revised 2 March 2020; accepted 3 March 2020; published 7

March 2020. 
WP benchmarks for each crop per climate zone. Increasing actual WPs in the state to benchmark levels will increase yields by $21 \%$ for maize and by $19 \%$ for soybean. The WP benchmark levels for the two crops presented here will help formulating targets for closing water productivity gaps and improving the sustainability of water use in the state.

Keywords: Water productivity gaps, Benchmarks, Yield gaps, Spatial and temporal variability, Water footprint

\section{Introduction}

The world's population will rise from 7.6 by 2017 to 9.8 billion by 2050 (UN-DESAPD, 2017), which will result in growing food demands. Agriculture accounts for 92 percent of the global water footprint (Hoekstra and Mekonnen, 2012). The global consumptive water use to produce food and fiber will increase from $6400 \mathrm{~km}^{3} / \mathrm{y}$ in 2000 to $9060 \mathrm{~km}^{3} / \mathrm{y}$ in 2050 (Rosegrant et al., 2009). The combined effect of the growing population, changing dietary preferences, and increased demand for biofuels, will strain the world's freshwater resources (Falkenmark et al., 2009; Gleick, 2003). Many parts of the world face severe freshwater scarcity during substantial parts of the year (Hoekstra et al., 2012; Mekonnen and Hoekstra, 2016; Oki and Kanae, 2006; Wada et al., 2011), which puts human water security and biodiversity at risk (Vörösmarty et al., 2010). As irrigation is the biggest water user, farmers may face increasing competition from other sectors for the limited water resources. Unless well managed, limited freshwater supply may constrain global food and fiber production (Rosegrant et al., 2009).

To address the rising pressure on water resources, there is a growing emphasis on increasing efficiency of water use in agriculture (Brauman et al., 2013; Foley et al., 2011; Giordano et al., 2017; Molden, 2007; Mueller et al., 2012; Passioura, 2006; Wallace and Gregory, 2002; West et al., 2014). Assessing water productivity (WP) and formulating WP benchmarks for crop production is important as a basis for formulating location- and crop-specific targets for water footprint reduction.

Various scholars have assessed the water productivity or water footprint for different crops, employing different tools and approaches. We find field trials, modelling studies, remote sensing-based approaches, and combinations of these. Field studies employ field measurements 
to determine the relation between water use and crop yield (Oweis et al., 2000; Rahman et al., 1995; Sadras et al., 2007; Sharma et al., 1990, 2001; Sharma et al., 2016; Zhang et al., 1998). WP estimates based on field trials are locally limited and valid for the field trial conditions such as climate, soil, water, and other farm management practices, making it difficult to scale up results to larger areas. Modelling studies use mathematic descriptions of the soil water profile and crop development to simulate soil moisture changes over time, water uptake by plants, transpiration, and evaporation from the soil, canopy cover, biomass growth and crop yield. Many modelling studies are locallevel studies, limited to certain locations and individual crops (Amir and Sinclair, 1991; Asseng et al., 2001; Grassini et al., 2009). Other studies are global, employing a high-resolution grid-based approach (Fader et al., 2010; Hanasaki et al., 2010; Liu et al., 2007; Mekonnen and Hoekstra, 2011; Siebert and Döll, 2010). With the exception of Liu et al. (2007), these global studies report the water footprint (WF) or virtual water content (VWC) of crops, but since the WF or VWC data can be inverted to show WP, results from those studies can easily be compared to outcomes from WP studies.

There are also various works on the case study area of this research, Nebraska, which is part of the Corn and Soybean Belt of the US. Djaman and Irmak (2012) and Irmak (2015) combined statistical maize yield data at county level, measured soil water content at field level, estimated evapotranspiration (ET) based on local weather data and assessed different WP indicators for irrigated maize in Nebraska. Djaman and Irmak (2012) studied the effect of irrigation on WP, while Irmak (2015) used a new irrigation-ET use efficiency indicator to measure the effect of different irrigation management on actual ET and assessed the efficiency of precipitation use. Irmak and Sharma (2015) and Sharma et al. (2016) assessed the WP of maize and soybean in Nebraska between 1986 and 2009 and found that the WP has increased for both crops. Grassini et al. (2011) employed the Hybrid-Maize model and measured irrigation application and maize yield data to assess potential yields for maize under irrigation in the Western Corn Belt region in the US. Grassini et al. (2011) have defined WP as the ratio of yield to total water supply (irrigation + in-season rain + soil water at planting), which is different to the other Nebraska based studies. The current study builds upon and extends these earlier Nebraska 
based studies by modelling crop WP at higher spatial resolution and over longer period. While Irmak and Sharma (2015) and Sharma et al. (2016) studies were similar to the current study, they did not model yield at high spatial resolution. The two studies have also used a very simple relation to model ET accounting only for precipitation and soil water holding capacity. The current study have used AquaCrop model to estimate ET accounting for soil properties, weather (precipitation, reference ET), tillage, and crop parameters. While the current study have accounted for the rainfed and irrigated harvested areas at high spatial resolution, the earlier studies have relied on county level data.

The development of WP benchmark levels for crop production can form a basis to identify WP gaps and formulate meaningful targets, aimed at decreasing water consumption per unit of crop produced (Hoekstra, 2013). In one of the early studies on WP benchmarks, Zwart et al. (2010) developed a global WP benchmark map for rainfed and irrigated wheat using remote sensing. In another global study, Mekonnen and Hoekstra (2014) developed consumptive WF (the inverse of WP) benchmarks of 124 different crops, using a soil-water-balance model. Zhuo et al. (2016) analyzed the extent to which WF benchmarks for crops need to be differentiated for different types of climate and soil, for winter wheat in China, finding that it is most crucial to distinguish between different climates when setting WF benchmarks. Karandish et al. (2018) assessed the volume of water savings that can be achieved in Iran when the WFs of 26 crops are reduced to benchmarks levels. Chukalla et al. (2015) showed the WF reduction that can be achieved for a number of different locations and crops when adopting improved agricultural practices, like soil mulching, drip and deficit irrigation. Chukalla et al. (2017) developed marginal cost curves in order to reduce the WF of irrigated crop production in cost-effective way. In another study, Edreira et al. (2018) used crop modelling to determine water-limited actual and potential WP in different cropping systems in the world for rainfed maize and wheat. The study developed WP benchmarks that are applicable at different scales, estimated the WP gaps and identified major factors that cause the gaps. Grassini et al. (2015) estimated yield gaps and attainable WP for soybean in the Western Corn Belt region in the US.

In the current study we develop WP benchmarks and identify the WP gaps and associated yield gaps for maize and soybean grown in 
Nebraska. WP is defined here as harvested crop yield (in fresh wet mass) per unit of total water consumed (evapotranspiration). First, we assess the temporal and spatial variability of the WP of maize and soybean. Next, we estimate WP benchmarks and current WP gaps. Finally, we estimate yield increases that could be achieved when closing the WP gaps.

\section{Method and data}

\subsection{Study area and period}

Nebraska has 93 counties and 23 Natural Resource Districts (NRDs). Maize and soybean are the two major crops produced, accounting for $49 \%$ and $27 \%$ of the total harvested crop area of the state, respectively (USDA, 2017). The other crops with large harvested area are hay/ haylage (14\% of the state's total harvested area) and winter wheat (6\%). With an irrigated area of 3.4 million ha, Nebraska ranks first in the nation in terms of total irrigated crop area (USDA-NASS, 2014). According to Sharma and Irmak (2012), Nebraska can be classified into four zones based on climatic, soil, and topographic characteristics (Fig. 1). The state's western part (Zone 1) and west central part (Zone 2) have a semi-arid climate, lower precipitation and soils with lower agronomic potential. Zone 3 has moderate precipitation and flat topography. The eastern part of the state (Zone 4) has relatively high annual rainfall and very productive soil with high agronomic productivity.

\subsection{Modelling crop yield and evapotranspiration}

Actual evapotranspiration (ET) and crop yield (Y) of maize and soybean in Nebraska were simulated for the period 1990-2014 with 1 $\times 1 \mathrm{~km}$ spatial resolution using FAO's AquaCrop model (Hsiao et al., 2009; Raes et al., 2009; Steduto et al., 2009). AquaCrop is a crop growth model that simulates soil water balance and crop biomass on a daily basis. Cumulative aboveground biomass is estimated as a product of normalized water productivity and the ratio of crop transpiration to reference evapotranspiration (Steduto et al., 2009). The crop 


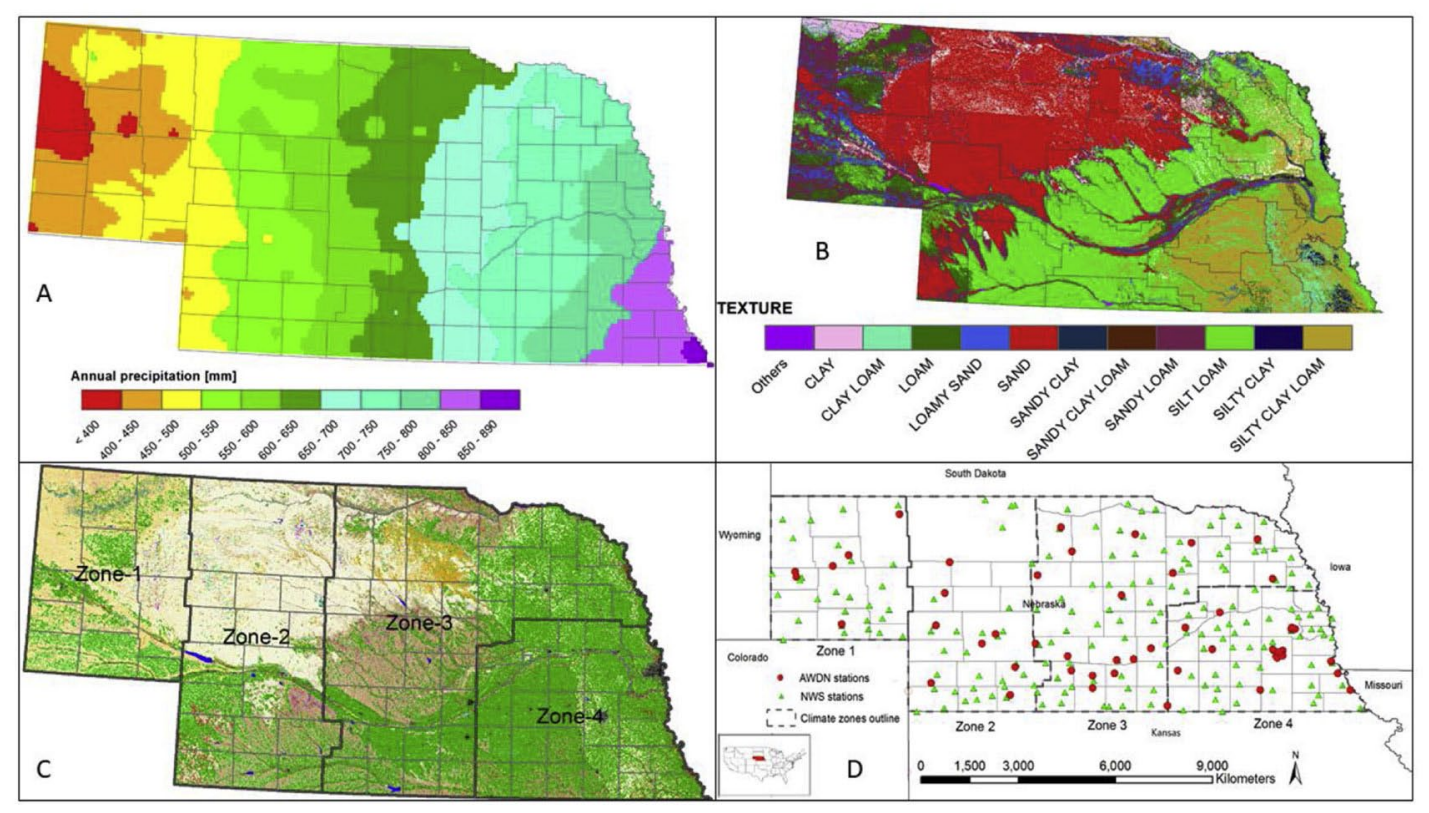

Fig. 1. Average annual precipitation (A) and soil texture (B) across the state of Nebraska, classification of the state in four zones (C), and location of weather stations (D). Data source: long term average annual precipitation (1981-2010) from Daly et al. (2008); soil texture from Soil Survey Staff (2017); land cover from UNL (2005); zones from Sharma and Irmak (2012).

parameters used include normalized water productivity, stomatal conductance, and canopy senescence (Steduto et al., 2009). In comparison to other models, AquaCrop requires few parameters but proves to be reliable (Steduto et al., 2012). AquaCrop has been validated and applied for various crops under different agricultural practices and environmental conditions.

In AquaCrop, the canopy cover (CC) directly influences crop biomass. Therefore, AquaCrop was calibrated by adjusting the crop parameters to simulate canopy cover development. The canopy growth coefficient (CGC), canopy decline coefficient (CDC), maximum canopy cover, days to emergence, days to senescence, and days to full maturity are the main parameters that determine the development of CC (Steduto et al., 2009). These parameters were iteratively adjusted until the simulated yields were found to be similar to field level measured yields. In addition, the planting density and reference Harvest Index (HIo) were adjusted to fit the modelled yield to the observed field level crop yield. The observed increase in crop yield over the last 
decades was due to crop varieties that have higher harvest index with higher planting density. The planting density and reference harvest index were adjusted to fit the modelled yield to observed yield data in different decades. Crop yield is equal to aboveground biomass times crop-specific harvest index. The latter is a function of timing and extent of water and temperature stresses (Raes et al., 2009). AquaCrop reports crop yields on a dry matter basis, here converted into fresh weight basis by dividing the modelled yield by $0.85 \mathrm{~kg}$ dry matter per $\mathrm{kg}$ fresh weight. The simulated yield pattern was scaled in order to match annual yield statistics at county level, separately for irrigated and rainfed croplands, as derived from USDA (2017). In Nebraska, notill system with no residue removal is practiced in close to $50 \%$ of the cropland. The tillage practice was modelled in AquaCrop by setting that $50 \%$ of the soil is covered by organic mulching.

\subsection{Assessing water productivity}

Water productivity (WP) is calculated as the total crop output divided by the total water applied or consumed. Depending on the different choices regarding the measurement of the numerator and denominator, WP can be defined in different ways. The numerator measuring output can be expressed in either total crop yield or the additional yield obtained from the use of irrigation water. The denominator is a water term expressed in volume of water available for the plant, water applied, or water consumed. The first definition of WP is expressed as crop yield divided by total available water, which is the sum of soil water at planting, in-season rainfall, and applied irrigation. In the second definition, WP is calculated as a ratio of crop yield and the total evapotranspiration over the crop growing season. Both definitions have their own strength and limitation and depending on the purpose one or both of the definitions can be used. In the current study we have adapted the second definition of the WP because it puts the emphasis on the water that we wish to conserve.

Different methods have been developed and applied to assess WP benchmarks. One method is to formulate WP benchmarks based on modelling of best agricultural practices (Chukalla et al., 2015, 2017). Another method is to set benchmarks based at the level of the highest WP found in a region with similar environmental characteristics 
(Schyns and Hoekstra, 2014) or to set benchmarks based on the 2oth or 25th percentile of best production (Karandish et al., 2018; Mekonnen and Hoekstra, 2014; Zhuo et al., 2016). Here, we apply this last method, using the WP achieved in the top 2oth percentile of crop production with highest WPs for each of the four climate zones.

\subsection{Data}

We obtained daily weather data (minimum and maximum temperature, precipitation, and reference ET) for the study period 1990-2014 for 61 stations of the Automated Weather Data Network (AWDN) of the High Plains Regional Climate Center (HPRCC, 2016). We used rainfall, minimum and maximum temperature data from 200 stations from the Cooperative Observer Network of the National Weather Service (NWS) to achieve denser spatial coverage (Fig. 1D). We also included climate data from neighboring states to allow for interpolation of data along Nebraska's borders. The weather data from the stations were interpolated through inverse distance weighing in the ArcGIS 10.4 environment. Soil layer thickness, saturated water content, field capacity and permanent wilting point, saturated hydraulic conductivity, electrical conductivity, and sand, silt, and clay content were derived from the SSURGO 2.2 database (Soil Survey Staff, 2017).

Rainfed and irrigated areas per crop at $1 \times 1 \mathrm{~km}^{2}$ spatial resolution were derived by combining USDA's crop-specific Cropland Data Layer (CDL) (USDA-NASS, 2017), the MIrAD-US irrigated area extent data (USGS, 2018), and crop specific county-level rainfed and irrigated area statistics obtained from USDA (USDA-NASS, 2014).

Both irrigated and rainfed crop yields in Nebraska strongly varied over the years due to climate variability, but show an increasing trend (Fig. 2). The average maize yield has increased 1.44 times from 1990 to 2014. Although, the rainfed maize yield is still $23 \%$ lower than the irrigated maize yield, it has increased by $77 \%$ from 1990 to 2014 . In the case of soybean, both the irrigated and rainfed yields have more than doubled from 1990 to 2014. This was achieved through enhanced crop genetics and better management of soil, nutrients, and water. However, there were major yield drops in 1993, 1995, 2000, 2002, 2006, and 2012, caused by unfavorable climatic conditions such as drought (for rainfed crops) and flooding (for all crops). 

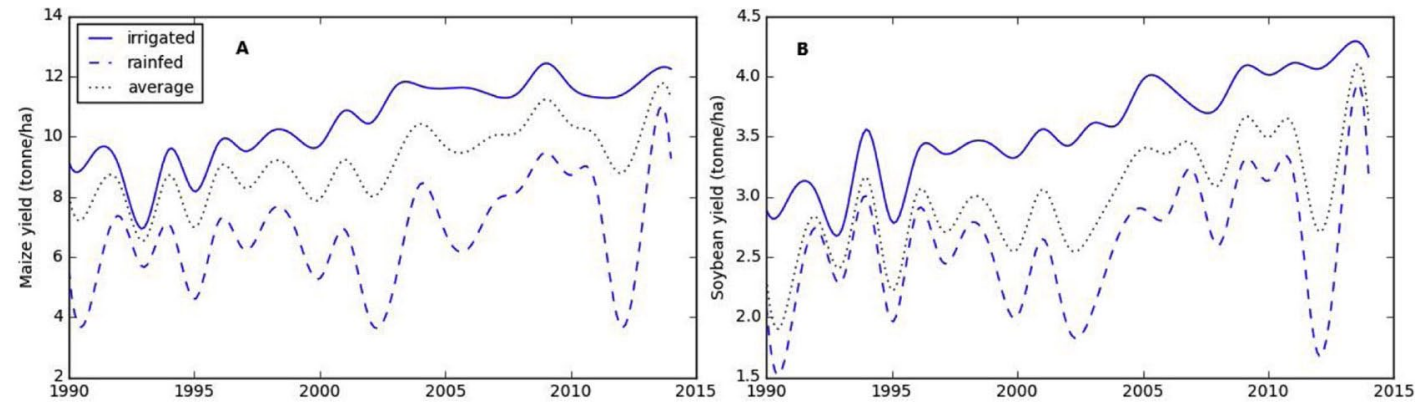

Fig. 2. State-level irrigated, rainfed, and average yield for maize (A) and soybean (B) from 1990 to 2014 in Nebraska. Data source: USDA (2017).

\section{Results}

\subsection{Temporal and spatial variation of water productivity in Nebraska}

The inter-annual variation in ET in irrigated and rainfed maize in Nebraska is shown in Fig. 3. As one may expect, the variability is most pronounced in rainfed areas, because ET depends here on rainfall variability while in irrigated areas soil water availability is kept more stable through irrigation. The inter-annual variation comes from year to year variation in evaporative demand and precipitation. The spread

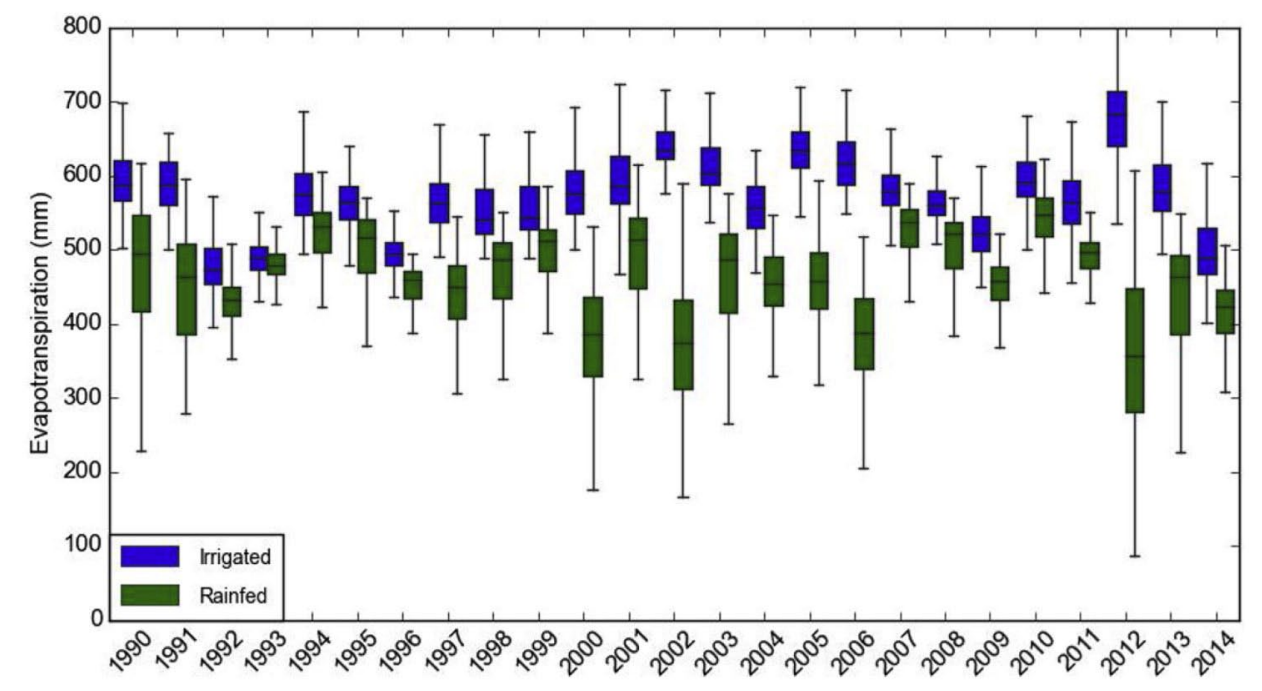

Fig. 3. Variation in actual evapotranspiration for rainfed and irrigated maize across Nebraska. Each boxplot refers to county-level modelled actual ET. 

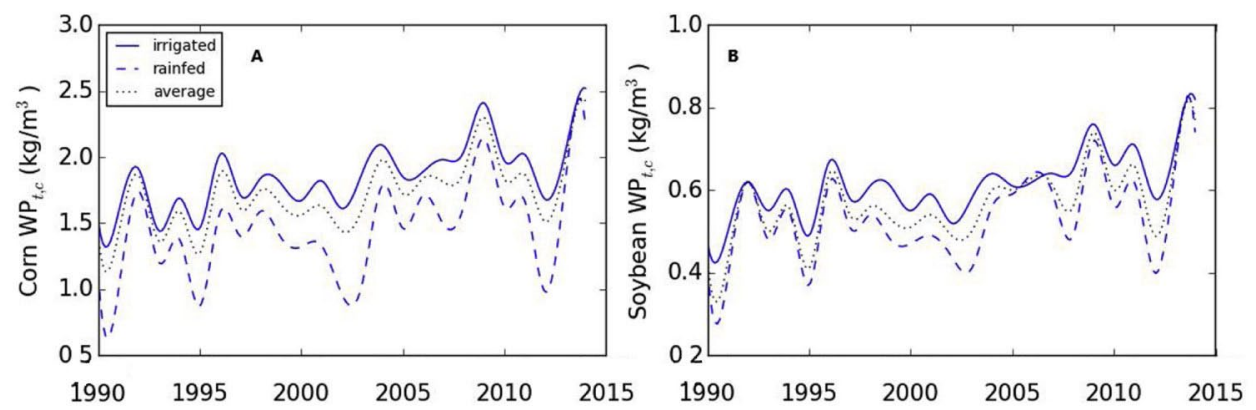

Fig. 4. WP for maize (A) and soybean (B) in irrigated and rainfed croplands in Nebraska.

in ET within the state shown every year, in particular for the rainfed fields, is due mainly to the east to west precipitation gradient. In Nebraska, precipitation drops from $900 \mathrm{~mm}$ in the eastern part to less than $400 \mathrm{~mm}$ in the western part (Fig. 1A). As a result, in the state's eastern part the available moisture can satisfy the crop water requirement (CWR) while in the west there is insufficient rain to meet CWR.

Between 1990 and 2014, the WP of the two crops significantly improved, in both irrigated and rainfed lands (Fig. 4). For both crops, the temporal variability in WP closely followed the variability in crop yield, which implies that WP highly correlates to land productivity. Over the time period considered, WP of irrigated maize increased by $65 \%$, and WP of rainfed maize by $98 \%$. The average WP of maize increased from 1.41 to $2.42 \mathrm{~kg} / \mathrm{m}^{3}$, mainly due to maize yield increases over the years. The WP of soybean increased by $72 \%$ and $79 \%$ for irrigated and rainfed fields, respectively.

The spatial variation in WP is shown in Fig. 5 for maize and Fig. 6 or soybean. A summary of WP for maize and soybean per NRD is provided in Table 1 . The east to west gradient in climate is clearly reflected in WP, which drops from eastern to western Nebraska, particularly for the rainfed crops. The spatial variation in WP can partly be explained by climate and soil differences across the state. In the east, with enough precipitation for crop growth, the crops are mostly rainfed. In the west, precipitation is lower, requiring additional irrigation for optimum crop production. Irrigated fields have higher yield, thus higher WP, because plants are not subject to water stress. For both crops, the low irrigated yield in the west is mostly due to the shorter growing season in the west compared to the east. Large differences 

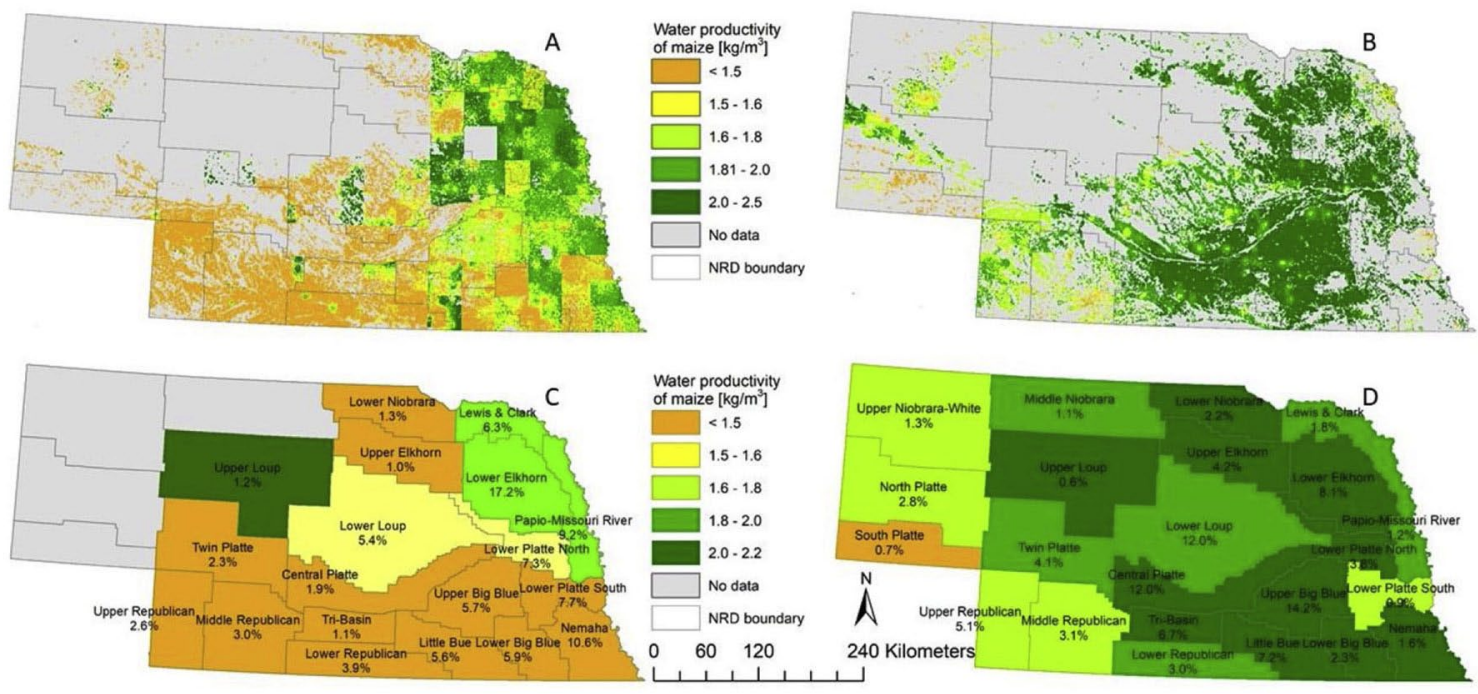

Fig. 5. Water productivity for irrigated and rainfed maize at different spatial levels: the WP of rainfed (A) and irrigated (B) maize at grid level with spatial resolution of $1 \mathrm{~km}^{2}$, and the WP of rainfed (C) and irrigated (D) maize at NRD level, derived as the production-weighted average of the grid data. The contribution of each NRD to the state's total rainfed or irrigated crop production is shown as a percentage in each NRD. NRDs with contribution below $0.5 \%$ are shown as no data. The values are averaged over the period 2010-2014.
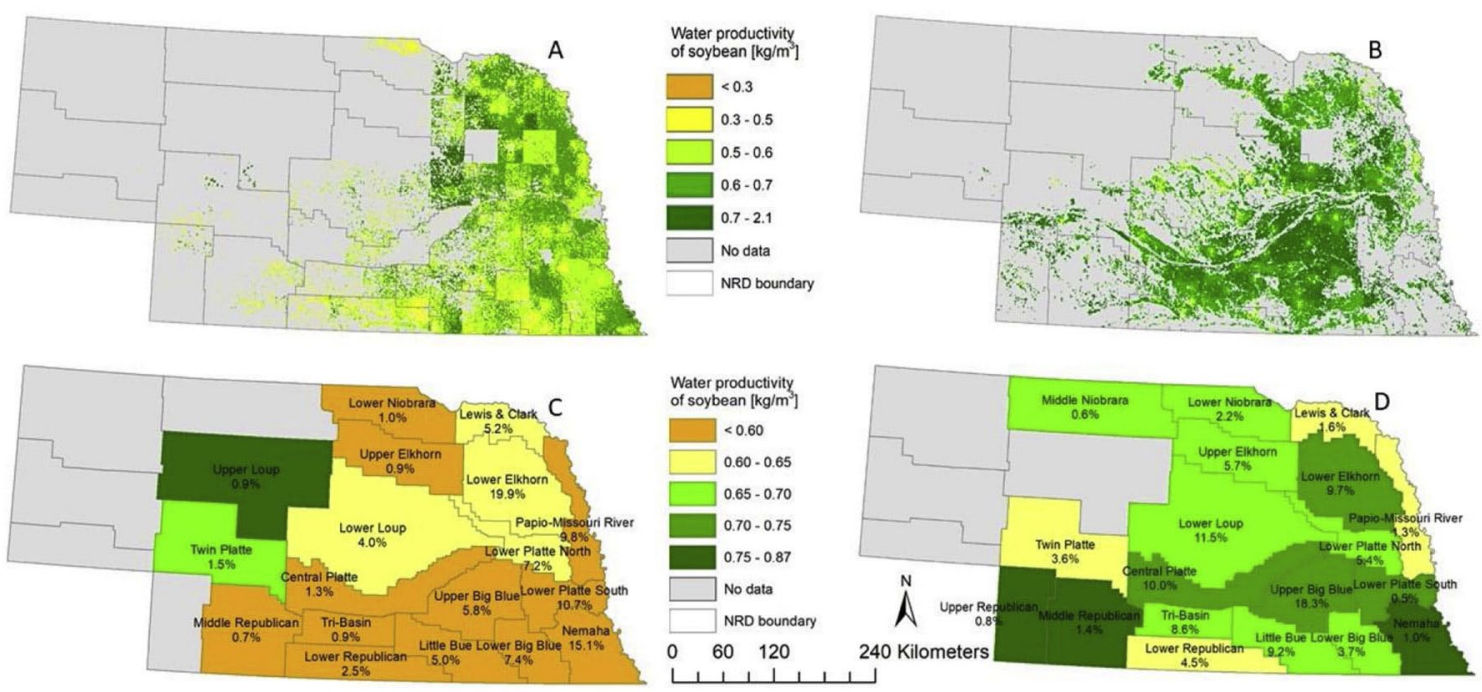

Fig. 6. Water productivity for irrigated and rainfed soybean at different spatial level: the WP of rainfed (A) and irrigated (B) soybean at grid level with spatial resolution of $1 \mathrm{~km}^{2}$, and the WP of rainfed (C) and irrigated (D) soybean at NRD level, derived as the production-weighted average of the grid data. The contribution of each NRD to the state's total rainfed or irrigated crop production is shown as a percentage in each NRD. NRDs with contribution below $0.5 \%$ are shown as no data. The values are averaged over the period 2010-2014. 
Table 1. Water productivity in irrigated and rainfed maize and soybean production per Natural Resource District (average over 2010-2014).

\begin{tabular}{|c|c|c|c|c|c|c|}
\hline \multicolumn{2}{|l|}{ Natural Resource District } & \multicolumn{2}{|l|}{ Maize } & \multicolumn{3}{|c|}{ Soybean } \\
\hline & rrigated & Rainfed & Average & Irrigated & Rainfed & Average \\
\hline Central Platte & 2.18 & 1.43 & 2.12 & 0.75 & 0.69 & 0.74 \\
\hline Lewis \& Clark & 2.33 & 1.56 & 1.87 & 0.78 & 0.71 & 0.72 \\
\hline Little Blue & 2.19 & 1.38 & 1.96 & 0.75 & 0.66 & 0.72 \\
\hline Lower Big Blue & 2.36 & 1.46 & 1.82 & 0.80 & 0.72 & 0.74 \\
\hline Lower Elkhorn & 2.39 & 1.52 & 1.97 & 0.80 & 0.74 & 0.76 \\
\hline Lower Loup & 2.16 & 1.47 & 2.04 & 0.74 & 0.67 & 0.73 \\
\hline Lower Niobrara & 2.30 & 1.54 & 2.12 & 0.78 & 0.68 & 0.75 \\
\hline Lower Platte North & 2.36 & 1.58 & 1.98 & 0.81 & 0.75 & 0.78 \\
\hline Lower Platte South & 2.29 & 1.51 & 1.69 & 0.82 & 0.75 & 0.75 \\
\hline Lower Republican & 2.05 & 1.25 & 1.70 & 0.71 & 0.59 & 0.67 \\
\hline Middle Niobrara & 2.12 & 1.43 & 2.10 & 0.70 & 0.65 & 0.70 \\
\hline Middle Republican & 1.90 & 1.17 & 1.62 & 0.62 & 0.54 & 0.59 \\
\hline Nemaha & 2.35 & 1.63 & 1.79 & 0.84 & 0.76 & 0.77 \\
\hline North Platte* & 1.72 & 0.81 & 1.66 & - & - & - \\
\hline Papio-Missouri River & 2.36 & 1.57 & 1.75 & 0.81 & 0.75 & 0.76 \\
\hline South Platte* & 1.63 & 0.86 & 1.50 & - & - & - \\
\hline Tri-Basin & 2.15 & 1.32 & 2.07 & 0.74 & 0.64 & 0.73 \\
\hline Twin Platte & 1.92 & 1.10 & 1.76 & 0.66 & 0.48 & 0.62 \\
\hline Upper Big Blue & 2.31 & 1.50 & 2.16 & 0.79 & 0.72 & 0.77 \\
\hline Upper Elkhorn & 2.31 & 1.46 & 2.21 & 0.78 & 0.69 & 0.76 \\
\hline Upper Loup & 2.01 & 1.08 & 1.65 & 0.76 & 0.57 & 0.66 \\
\hline Upper Niobrara-White* & 1.76 & 0.72 & 1.66 & - & - & - \\
\hline Upper Republican* & 1.88 & 1.02 & 1.66 & - & - & - \\
\hline
\end{tabular}

* Soybean is not common in these NRDs.

in WP across the state are also caused by differences in agricultural practices, including irrigation, soil, and nutrient management.

The average and range of the WP values for maize and soybean are comparable to the value obtained by Irmak and Sharma (2015) and Sharma et al. (2016). While the current estimate of the WP of maize is $3-6 \%$ larger, the estimate for soybean WP is $2-5 \%$ smaller than the estimate by Irmak and Sharma (2015).

\subsection{Water productivity benchmarks and current water produc- tivity gaps}

Fig. 7 shows the relationship between crop yield and ET over the growing season for maize and soybean. Each point represents actual yield and modelled ET for a certain county and year in the period 2010-2014. This period contains years with normal precipitation 

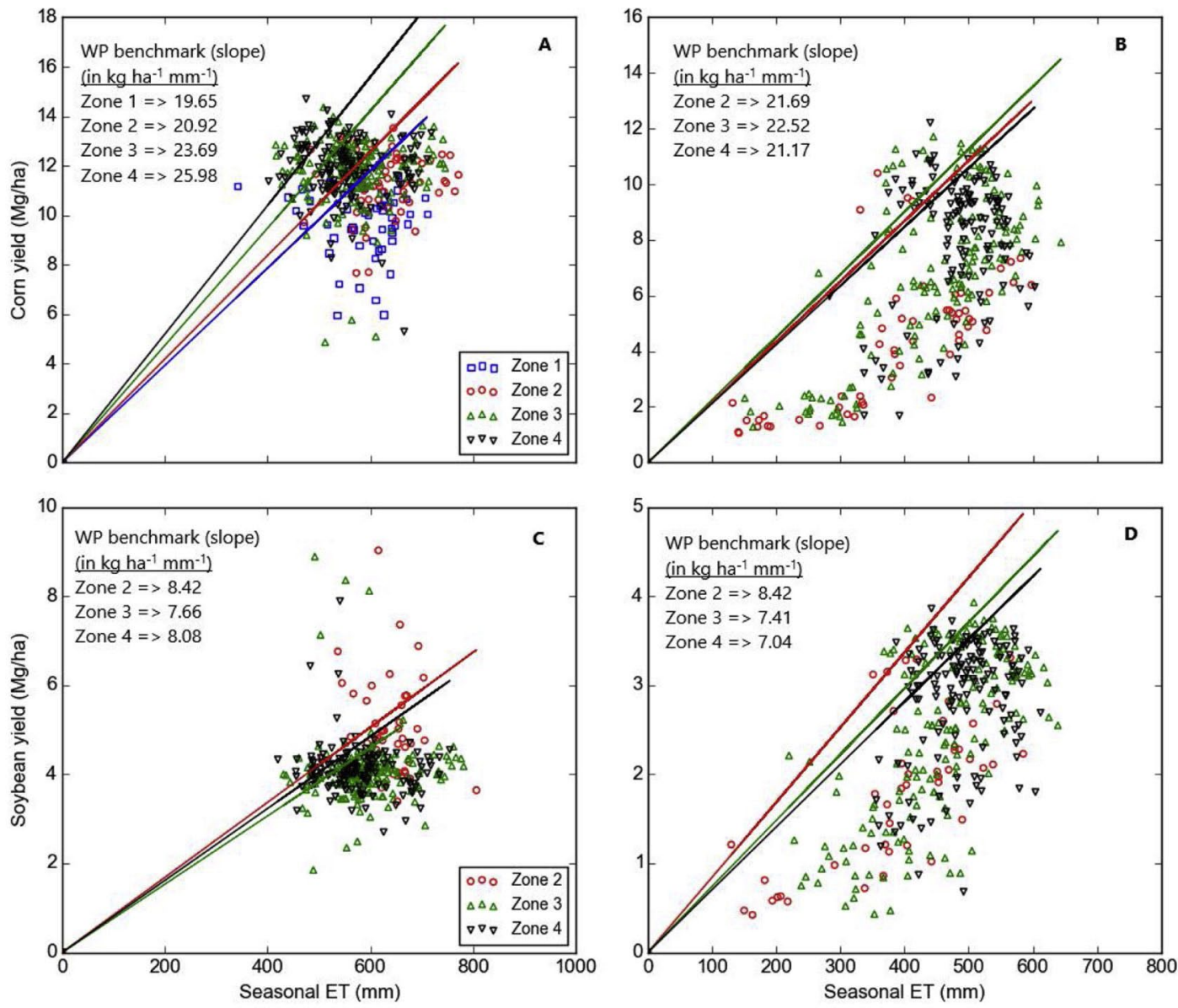

Fig. 7. Relationship between county-level crop yield and evapotranspiration over the growing season for irrigated maize (A), rainfed maize (B), irrigated soybean (C) and rainfed soybean (D) in Nebraska. Each data point represents the combination of yield and ET in a particular county and year in the period 2010-2014. The points are shown in four clouds, each cloud representing one climate zone. Per climate zone, the WP benchmark is shown as a line in the ET-Y graph. Soybean is not common in Zone 1.

and a severe drought year (2012). For both maize and soybean, the spread of rainfed yield is larger than the spread of the irrigated yield. The rainfed yield ranges from 0.7 to $12.0 \mathrm{Mg} \mathrm{ha}^{-1}$ for maize and from 0.4 to $3.9 \mathrm{Mg} \mathrm{ha}^{-1}$ for soybean. This is due to differences in the evaporative demand and precipitation across the state and over different years. The WP of both crops shows large variation across the state, related to spatial differences in climate, but also to differences in soil and water management, planting date and duration of the growing 
period. The slopes shown in each graph represents the 2oth percentile benchmark values for each crop, differentiating between climate zones and between irrigated and rainfed lands. For irrigated maize, the WP benchmark gradually increases from west to east of the state. The benchmark for irrigated maize is larger than for rainfed maize. For rainfed maize, the WP benchmark in Zone 1 is remarkably lower than for the other zones, due to the unfavorable growing conditions in terms of precipitation. Soybean do not show large differences in WP benchmarks across the three zones in which it is grown and between irrigated and rainfed lands. For soybean, the WP benchmark for Zone 2 is slightly higher than for Zones 3 and 4 in both irrigated and rainfed fields. In the case of irrigated soybean, the reason is the larger yields in Zone 2 compared to Zones 3 and 4. For rainfed soybean, the higher WP benchmark for Zone 2 is due to relatively low seasonal ET, which relates to lower precipitation in Zone 2 compared to Zones 3 and 4 .

Setting WP benchmarks per agro-climate zone is the first step toward reducing the water footprint of crop production. The wide variability in the estimated WP at county level indicates the existence of non-climate related factors that affect the WP. Thus, there is a need to identify factors that influence yield and WP in different fields across the state and define WP benchmarks that account for the differences in climate and soil properties that exist across the state.

Fig. 8 shows actual WP for maize and soybean as well as the WP gap. The WP gap was estimated, per crop and climate zone and differentiating between irrigated and rainfed lands, as a difference between the 2oth percentile benchmark value (Fig. 7) and the actual WP. The WP gaps are larger for the rainfed crops. The WP gaps for irrigated maize and soybean are due to limiting factors other than water. Factors such as pest, soil properties, cold stress, frost and management practices play an important role in limiting actual WP.

\subsection{Yield increases when closing the WP gaps}

Reducing a WP gap means that either yield can be increased at given ET or that ET can be reduced at given yield. When reducing the WP gaps, significant yield increases may be achieved. If these yield increases come along with reduced total harvested cropland areas, this can result in significant water savings. The WP benchmark per crop 

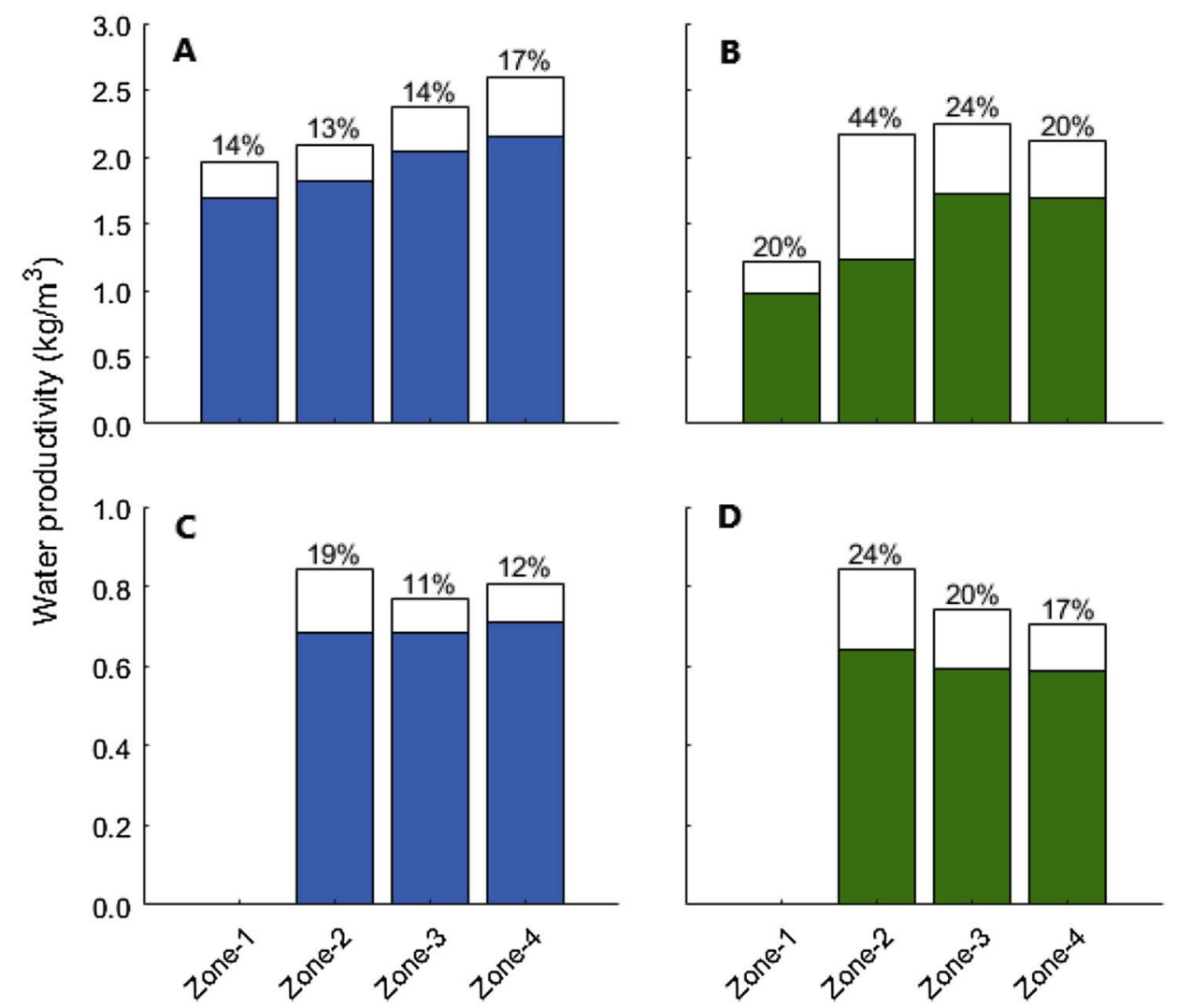

Fig. 8. Actual water productivity and the WP gap for irrigated maize (A), rainfed maize (B), irrigated soybean (C) and rainfed soybean (D) across the four climate zones of the state. The colored portion shows the actual WP and the white portion indicates the WP gap. Soybean is not common in Zone 1. The percentages shown above each bar refer to the WP gap expressed as a percentage of the potential WP. The data are averaged over the period 2010-2014.

per climate zone was used to estimate the yield gap, which is defined as the difference between the estimated potential and observed county level yields for maize and soybean. The irrigated and rainfed yield gaps for maize and soybean are presented Fig. 9. Due to differences in climate, soil properties and crop cultivars across the state, there is a wide range of values in the yield gap for the two crops across the state. For maize, the estimated rainfed yield gap varies across zones from 0.57 to $4.1 \mathrm{Mg} \mathrm{ha}^{-1}$ and the irrigated yield gap from 2.1 to $2.6 \mathrm{Mg} \mathrm{ha}^{-1}$. For soybean, the rainfed yield gap varies from 0.65 to $1.5 \mathrm{Mg} \mathrm{ha}^{-1}$, and the irrigated yield gap from 0.65 to $0.68 \mathrm{Mg} \mathrm{ha}^{-1}$. The average maize yield gap in Nebraska was 2.3 $\mathrm{Mg} \mathrm{ha}^{-1}$ for irrigated lands and $2.5 \mathrm{Mg}$ 


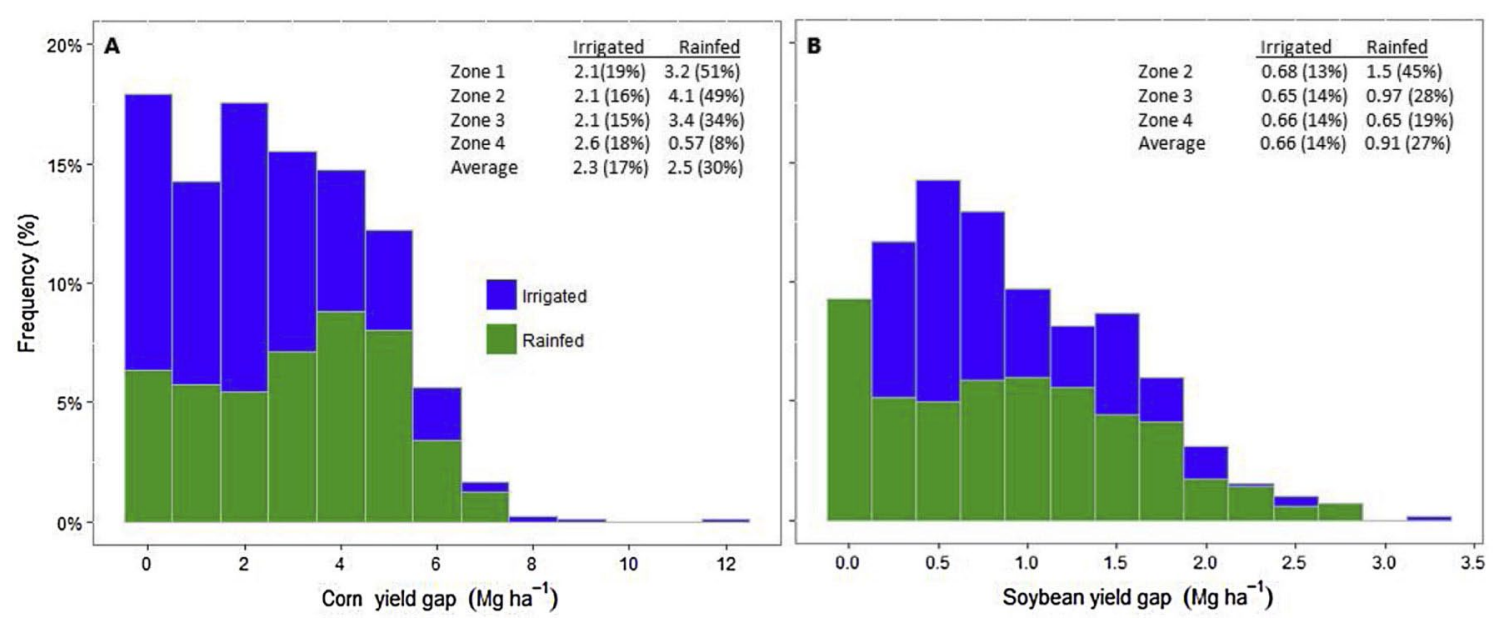

Fig. 9. Frequency distribution of yield gap for irrigated and rainfed maize (A) and soybean (B) across the four climate zones of Nebraska. The yield gap was calculated based on the WP benchmarks per climate zone. The average yield gap per climate zone, for both irrigated and rainfed lands, are tabulated, given in absolute terms $\left(\mathrm{Mg} \mathrm{ha}^{-1}\right)$ and as a percentage of the potential yield. The data are averaged over the period 2010-2014.

$\mathrm{ha}^{-1}$ for rainfed lands. For soybean, the average yield gap was $0.66 \mathrm{Mg}$ $\mathrm{ha}^{-1}$ for irrigated lands and $0.91 \mathrm{Mg} \mathrm{ha}^{-1}$ for rainfed lands. Closing the WP gap will help to close the yield gap, providing the opportunity to produce the same amount of crop with less water, thus reducing pressure on groundwater resources in the state. Optimal soil, fertilizer, and water management will be needed to close the water and yield gaps. By increasing actual WP levels to benchmark levels in each climate zone, in both rainfed and irrigated agriculture, production of maize and soybean in the state will increase by $20 \%$ and $19 \%$, respectively.

\section{Conclusion}

Nebraska has one of the highest maize and soybean yields in the country and the world. Yield levels of maize and soybean have grown considerably over the last 25 years. This increase in crop yields combined with the adoption of farm level management and vast irrigation systems has helped to increase the WP of crop production in the state. Between 1990 and 2014, WPs of maize and soybean have increased 
on average by $71 \%$ and $79 \%$, respectively. The WP of the two crops increases as we go from the western to the eastern part of the state. This change follows the spatial gradient in precipitation, soil quality, and growth season length within the state.

We show that WP in maize and soybean production can still be increased; yields can be further raised by closing the WP gaps without putting additional pressure on the water resources. If, with raising yields and reduced cultivated area, the overall production levels of maize and soybean remain constant, the overall water consumption of crop production in that state can actually be reduced.

The current study has assessed the WP at high spatial resolution and over longer period. The study further develops WP benchmark and estimated the yield and WP gaps across the state. The WP benchmark could be useful for developing strategies aimed at reducing the water needed to produce crop production. The quantitative analysis on the actual and attainable WP is fundamental in the effort to improve WP and improve the sustainability of water use in the state. However, the analyses are not without limitations. The study assesses the WP variations across the state but didn't identify factors such as climate, soil properties, and field level soil and water management measures that influence yield and WP in different fields across the state. The result and the value of the analysis could be improved if these factors are taken into account.

By combining different field level management strategies one can raise water productivity, which means either more crop per hectare with the same ET or less ET per hectare while producing the same amount of crop (or a combination of both). More crop per hectare can be achieved by better crop cultivars and nutrient and pest management, while a reduction in ET can be achieved by measures like mulching, deficit irrigation and precision irrigation. Mulching of the soil can reduce unproductive soil evaporation without affecting the crop yield and thus improve WP. Deficit irrigation can increase WP by reducing net irrigation application and evapotranspiration over the growing period, possibly at the cost of some yield, but with a percentage of yield loss that is substantially smaller than the percentage of water gain. Precision irrigation enables the spatial differentiation of irrigation amounts according to local needs, thus reducing overall water consumption. Increasing water productivity is one factor among 
others, like the income of farmers, the sustainable use of groundwater and streams, and the level of water pollution from excessive nutrient use. All these factors need to be taken into consideration in order to understand possible trade-offs.

Competing Interests The authors declared that they have no known competing financial interests or personal relationships that could have appeared to influence the work reported in this paper.

Acknowledgement In memory of Prof. ir.dr. Arjen Y. Hoekstra (1967-2019) who passed away suddenly before the publication of this article.

Appendix A. Supplementary data Supplementary material related to this article is attached to the repository record. It can also be found, in the online version, at https://doi.org/10.1016/j.agwat.2020.106122 .

\section{References}

Amir, J., Sinclair, T.R., 1991. A model of water limitation on spring wheat growth and yield. Field Crops Res. 28, 59-69. https://doi. org/10.1016/0378-4290(91)90074-6

Asseng, S., Turner, N.C., Keating, B.A., 2001. Analysis of water- and nitrogenuse efficiency of wheat in a Mediterranean climate. Plant Soil 233, 127-143. https://doi.org/10.1023/a:1010381602223

Brauman, K.A., Siebert, S., Foley, J.A., 2013. Improvements in crop water productivity increase water sustainability and food security-a global analysis. Environ. Res. Lett. 8, 024030.

Chukalla, A.D., Krol, M.S., Hoekstra, A.Y., 2015. Green and blue water footprint reduction in irrigated agriculture: effect of irrigation techniques, irrigation strategies and mulching. Hydrol. Earth Syst. Sci. Discuss. 19, 4877-4891. https://doi.org/10.5194/hess-19-4877-2015

Chukalla, A.D., Krol, M.S., Hoekstra, A.Y., 2017. Marginal cost curves for water footprint reduction in irrigated agriculture: guiding a cost-effective reduction of crop water consumption to a permit or benchmark level. Hydrol. Earth Syst. Sci. Discuss. 21, 3507-3524. https://doi.org/10.5194/hess-21-3507-2017

Daly, C., et al., 2008. Physiographically sensitive mapping of climatological temperature and precipitation across the conterminous. US Int. J. Climatol. 28, 2031-2064. https://doi.org/10.1002/joc.1688

Djaman, K., Irmak, S., 2012. Soil water extraction patterns and crop, irrigation, and evapotranspiration water use efficiency of maize under full and limited irrigation and rainfed settings. Trans. ASABE 55 (1223). https://doi. org/10.13031/2013.42262 
Edreira, J.I.R., Guilpart, N., Sadras, V., Cassman, K.G., van Ittersum, M.K., Schils, R.L.M., Grassini, P., 2018. Water productivity of rainfed maize and wheat: a local to global perspective. Agric. For. Meteorol. 259, 364-373. https://doi. org/10.1016/j.agrformet.2018.05.019

Fader, M., Rost, S., Müller, C., Bondeau, A., Gerten, D., 2010. Virtual water content of temperate cereals and maize: present and potential future patterns. J. Hydrol. (Amst) In Press, Corrected Proof.

Falkenmark, M., Rockström, J., Karlberg, L., 2009. Present and future water requirements for feeding humanity. Food Secur. 1, 59-69. https://doi. org/10.1007/s12571-008-0003-X

Foley, J.A., et al., 2011. Solutions for a cultivated planet. Nature 478, 337-342.

Giordano, M., Turral, H., Scheierling, S.M., Tréguer, D.O., McCornick, P.G., 2017. Beyond “More Crop Per Drop": Evolving Thinking on Agricultural Water Productivity. International Water Management Institute (IWMI) and The World Bank, Colombo, Sri Lanka and Washington, DC, USA. https://doi. org/10.5337/2017.202

Gleick, P.H., 2003. Global freshwater resources: soft-path solutions for the 21st century. Science 302, 1524-1528.

Grassini, P., Hall, A.J., Mercau, J.L., 2009. Benchmarking sunflower water productivity in semiarid environments. Field Crops Res. 110, 251-262. https:// doi.org/10.1016/j.fcr.2008.09.006

Grassini, P., Yang, H., Irmak, S., Thorburn, J., Burr, C., Cassman, K.G., 2011. Highyield irrigated maize in the Western U.S. Corn Belt: II. Irrigation management and crop water productivity. Field Crops Res. 120, 133-141. https://doi. org/10.1016/j.fcr.2010.09.013

Grassini, P., Torrion, J.A., Yang, H.S., Rees, J., Andersen, D., Cassman, K.G., Specht, J.E., 2015. Soybean yield gaps and water productivity in the western U.S. Corn Belt Field Crops Res. 179, 150-163. https://doi.org/10.1016/j.fcr.2015.04.015

Hanasaki, N., Inuzuka, T., Kanae, S., Oki, T., 2010. An estimation of global virtual water flow and sources of water withdrawal for major crops and livestock products using a global hydrological model. J. Hydrol. (Amst) 384, 232-244. https://doi.org/10.1016/j.jhydrol.2009.09.028

Hoekstra, A.Y., 2013. The Water Footprint of Modern Consumer Society. Routledge, London, UK.

Hoekstra, A.Y., Mekonnen, M.M., 2012. In: USA. The Water Footprint of Humanity Proceedings of the National Academy of Sciences 109. pp. 3232-3237. https:// doi.org/10.1073/pnas.1109936109

Hoekstra, A.Y., Mekonnen, M.M., Chapagain, A.K., Mathews, R.E., Richter, B.D., 2012. Global monthly water scarcity: blue water footprints versus blue water availability. PLoS One 7, e32688. https://doi.org/10.1371/journal. pone.0032688

HPRCC, 2016. Automated Weather Data Network (AWDN). High Plains Regional Climate Center (HPRCC). Accessed 15 September 2016. https://hprcc.unl.edu/ awdn.php 
Hsiao, T.C., Heng, L., Steduto, P., Rojas-Lara, B., Raes, D., Fereres, E., 2009. AquaCrop-the FAO crop model to simulate yield response to water: III. Parameterization and Testing for Maize Agron J 101, 448-459. https://doi. org/10.2134/agronj2008.0218s

Irmak, S., 2015. Interannual variation in long-term center pivot-irrigated maize evapotranspiration and various water productivity response indices. II: irrigation water use efficiency, crop WUE, evapotranspiration WUE, irrigation-evapotranspiration use efficiency, and precipitation use efficiency. J. Irrig. Drain. Eng. 141, 04014069. https://doi.org/10.1061/(ASCE) $\underline{\text { IR.1943-4774.0000826 }}$

Irmak, S., Sharma, V., 2015. Large-scale and long-term trends and magnitudes in irrigated and rainfed maize and soybean water productivity: grain yield and evapotranspiration frequency, crop water use efficiency, and production. Functions Transactions of the ASABE 58 (103). https://doi.org/10.13031/ trans.58.10784

Karandish, F., Hoekstra, A.Y., Hogeboom, R.J., 2018. Groundwater saving and quality improvement by reducing water footprints of crops to benchmarks levels. Adv. Water Resour. https://doi.org/10.1016/j.advwatres.2018.09.011

Liu, J., Williams, J.R., Zehnder, A.J.B., Yang, H., 2007. GEPIC - modelling wheat yield and crop water productivity with high resolution on a global scale. Agric. Syst. 94, 478-493. https://doi.org/10.1016/j.agsy.2006.11.019

Mekonnen, M.M., Hoekstra, A.Y., 2011. The green, blue and grey water footprint of crops and derived crop products. Hydrol. Earth Syst. Sci. Discuss. 15, 157716oo. https://doi.org/10.5194/hess-15-1577-2011

Mekonnen, M.M., Hoekstra, A.Y., 2014. Water footprint benchmarks for crop production: a first global assessment. Ecol. Indic. 46, 214-223. https://doi. org/10.1016/j.ecolind.2014.06.013

Mekonnen, M.M., Hoekstra, A.Y., 2016. Four billion people facing severe water scarcity. Sci. Adv. 2, e1500323. https://doi.org/10.1126/sciadv.1500323

Molden, D. (Ed.), 2007. Water for Food, Water for Life: A Comprehensive Assessment of Water Management in Agriculture. Earthscan/International Water Management Institute, London, UK / Colombo, Sri Lanka.

Mueller, N.D., Gerber, J.S., Johnston, M., Ray, D.K., Ramankutty, N., Foley, J.A., 2012. Closing yield gaps through nutrient and water management. Nature 490, 254-257 http://www.nature.com/nature/journal/v49o/n7419/abs/ nature11420.html\#supplementary-information

Oki, T., Kanae, S., 2006. Global hydrological cycles and world water resources. Science 313, 1068-1072. https://doi.org/10.1126/science.1128845

Oweis, T., Zhang, H., Pala, M., 200o. Water use efficiency of rainfed and irrigated bread wheat in a Mediterranean environment. Agron J 92, 231-238. https:// doi.org/10.2134/agronj2000.922231x

Passioura, J., 2006. Increasing crop productivity when water is scarce-from breeding to field management. Agric. Water Manag. 8o, 176-196. 
Raes, D., Steduto, P., Hsiao, T.C., Fereres, E., 2009. AquaCrop The FAO crop model to simulate yield response to water: II. Main algorithms and software description. Agron. J. 101, 438-447. https://doi.org/10.2134/agronj2008.0140s

Rahman, S.M., Khalil, M.I., Ahmed, M.F., 1995. Yield-water relations and nitrogen utilization by wheat in salt-affected soils of Bangladesh. Agric. Water Manag. 28, 49-56. https://doi.org/10.1016/0378-3774(95)01168-I

Rosegrant, M.W., Ringler, C., Zhu, T., 2009. Water for agriculture: maintaining food security under growing scarcity. Annu. Rev. Environ. Resour. 34, 205-222. https://doi.org/10.1146/annurev.environ.030308.090351

Sadras, V.O., Grassini, P., Steduto, P., 2007. Status of Water Use Efficiency of Main Crops. Food and Agricultural Organization, Rome, Italy.

Schyns, J.F., Hoekstra, A.Y., 2014. The added value of water footprint assessment for national water policy: a case study for Morocco. PLoS One 9, e99705. https://doi.org/10.1371/journal.pone.0099705

Sharma, V., Irmak, S., 2012. Mapping spatially interpolated precipitation, reference evapotranspiration, actual crop evapotranspiration, and net irrigation requirements in Nebraska: part I. precipitation and reference evapotranspiration. Trans. ASABE 55 (907). https://doi. org/10.13031/2013.41523

Sharma, D.K., Kumar, A., Singh, K.N., 1990. Effect of irrigation scheduling on growth, yield and evapotranspiration of wheat in sodic soils. Agric. Water Manag. 18, 267-276. https://doi.org/10.1016/0378-3774(90)90048-4

Sharma, N.K., Samra, J.S., Singh, H.P., 2001. Influence of boundary plantation of poplar (Populus deltoides M.) on soil-water use and water use efficiency of wheat. Agric. Water Manag. 51, 173-185. https://doi.org/10.1016/ S0378-3774(01)00089-0

Sharma, V., Irmak, S., Djaman, K., Sharma, V., 2016. Large-scale spatial and temporal variability in evapotranspiration, crop water-use efficiency, and evapotranspiration water-use efficiency of irrigated and rainfed maize and soybean. J. Irrig. Drain. Eng. 142, 04015063. https://doi.org/10.1061/(ASCE) IR.1943-4774.0000985

Siebert, S., Döll, P., 2010. Quantifying blue and green virtual water contents in global crop production as well as potential production losses without irrigation. J. Hydrol. (Amst) 384, 198-217.

Soil Survey Staff, 2017. Soil Survey Geographic (SSURGO) Database. Natural Resources Conservation Service, United States Department of Agriculture Accessed 15 January 2017. https://sdmdataaccess.sc.egov.usda.gov

Steduto, P., Hsiao, T.C., Raes, D., Fereres, E., 2009. AquaCrop-the FAO crop model to simulate yield response to water: I. concepts and underlying principles. Agron. J. 101, 426-437. https://doi.org/10.2134/agronj2008.0139s

Steduto, P., Hsiao, T.C., Fereres, E., Raes, D., 2012. Crop Yield Response to Water. Food and Agriculture Organization (FAO), Rome, Italy.

UN-DESAPD, 2017. World Population Prospects: the 2017 Revision, Key Findings and Advance Tables Vol Working Paper No. ESA/P/WP/248. United Nations, Department of Economic and Social Affairs, Population Division, New York. 
UNL, 2005. Nebraska Land Cover Classification. University of NebraskaLincoln, School of Natural Resources, Center for Advanced Land Management Information Technologies (CALMIT). Accessed September 2017. http://snr.unl. edu/data/download/geographygis/2005 NEGAP landcover.zip

USDA, 2017. Agricultural Statistics Data Base (Quick Stats). U.S. Department of Agriculture, National Agricultural Statistics Service (USDA-NASS). https:// quickstats.nass.usda.gov/

USDA-NASS, 2014. 2012 Census of Agriculture: Farm and Ranch Irrigation Survey (2013). U.S. Department of Agriculture-National Agricultural Statistics Service (USDA-NASS), Washington, DC.

USDA-NASS, 2017. Cropland Data Layer, Published Crop-specific Data Layer [Online]. U.S. Department of Agriculture-National Agricultural Statistics Service (USDA-NASS). https://nassgeodata.gmu.edu/CropScape/

Vörösmarty, C.J., et al., 2010. Global threats to human water security and river biodiversity. Nature 467, 555-561.

Wada, Y., van Beek, L.P.H., Viviroli, D., Dürr, H.H., Weingartner, R., Bierkens, M.F.P., 2011. Global monthly water stress: 2. Water demand and severity of water stress Water Resource Research 47, Wo7518. https://doi. org/10.1029/2010wroog792

Wallace, J.S., Gregory, P.J., 2002. Water resources and their use in food production systems. Aquat. Sci. 64, 363-375.

West, P.C., et al., 2014. Leverage points for improving global food security and the environment. Science 345, 325-328. https://doi.org/10.1126/science.1246067

Zhang, J., Sui, X., Li, B., Su, B., Li, J., Zhou, D., 1998. An improved water-use efficiency for winter wheat grown under reduced irrigation. Field Crops Res. 59, 91-98. https://doi.org/10.1016/S0378-4290(98)00104-X

Zhuo, L., Mekonnen, M.M., Hoekstra, A.Y., 2016. Benchmark levels for the consumptive water footprint of crop production for different environmental conditions: a case study for winter wheat in China. Hydrol. Earth Syst. Sci. Discuss. 20, 4547-4559. https://doi.org/10.5194/hess-20-4547-2016

Zwart, S.J., Bastiaanssen, W.G.M., de Fraiture, C., Molden, D.J., 2010. A global benchmark map of water productivity for rainfed and irrigated wheat. Agric. Water Manag. 97, 1617-1627. 